\title{
ARTICLE
}

\section{Variability of environmental heterogeneity in northern Patagonia, Chile: effects on the spatial distribution, size structure and abundance of chlorophyll-a}

Variabilidad de la heterogeneidad ambiental en la Nor-Patagonia, Chile: efectos sobre la distribución espacial, abundancia y estructura de tamaños de la clorofila- $a$

\author{
Viviana Martínez', Carlos Lara ${ }^{2}$, Nelson Silva ${ }^{3}$, \\ Víctor Gudiño ${ }^{4}$ and Vivian Montecino ${ }^{5}$
}

\begin{abstract}
${ }^{1}$ Asesorías Ambientales y Pesqueras. Ltda, Av. Magallanes 1025, depto. 304, Concón, Chile. v.martinezb@gmail.com ${ }^{2}$ Centro de Estudios Avanzados en Zonas Áridas y Doctorado en Biología y Ecología Aplicada, Facultad de Ciencias del Mar, Universidad Católica del Norte, Larrondo1281, Coquimbo, Chile

${ }^{3}$ Escuela de Ciencias del Mar, Pontificia Universidad Católica de Valparaíso, Avenida. Altamirano 1480, Valparaíso, Chile ${ }^{4}$ Facultad de Ciencias del Mar y Recursos Naturales, Universidad de Valparaíso, Avenida Borgoño 16344, Reñaca, Chile ${ }^{5}$ Departamento de Ciencias Ecológicas, Facultad de Ciencias, Universidad de Chile, Las Palmeras 3425. Casilla 653, Santiago, Chile.vivianmontecino@uchile.cl
\end{abstract}

Resumen.- La cadena de islas incluyendo Desertores-Apiao y Quemchi situada en el Mar Interior de Chiloé, en la Patagonia chilena norte (41$44^{\circ} \mathrm{S}$ ), actúa como una barrera natural para el flujo de agua en dirección norte-sur que influye en el intercambio y circulación entre las micro cuencas norte y sur. La micro cuenca norte se caracteriza por el dominio de las aguas estuarinas superficiales mientras que la micro cuenca sur se encuentra afectada por aguas Subantárticas y Ecuatoriales Subsuperficiales desde el océano costero adyacente. Esta situación determina diferencias claves en la distribución espacial, abundancia y composición por tamaño de la biomasa autotrófica (medida como clorofila-a). Estas diferencias cuali y cuantitativas de clorofila-a se evaluaron en dos épocas contrastantes durante expediciones en 2004 y 2005 (Cruceros de Investigación Marina, CIMAR 10 y 11 Fiordos). En ambas micro cuencas, se analizaron parámetros físicos, químicos y bioópticos de la capa de mezcla superficial junto con imágenes satelitales compuestas de 8 días de clorofila-a (MODIS-AQUA). La principal diferencia de la heterogeneidad ambiental entre zonas fue determinada por la concentración de nitratos y ácido silícico. En primavera la abundancia de la clorofila-a mostró alta variabilidad en ambas micro cuencas y con predominancia del micro-fitoplancton. En el invierno austral el micro-fitoplancton también fue dominante en una amplia gama de condiciones ambientales, pero estrechamente vinculada a zonas con alta concentración de ácido silícico. Las fracciones más pequeñas, sin embargo, dominaron en un entorno más homogéneo caracterizado por una mayor concentración de nitratos. Aunque los nutrientes no se agotan en el área de estudio, la razón nitrato/ácido silícico influencia claramente la abundancia, la composición por tamaño y la estructura espacial de la comunidad autotrófica durante invierno bajo menor disponibilidad de luz y procesos oceanográficos más complejos durante la primavera.

Palabras clave: Geoestadística, Mar Interior de Chiloé, nutrientes, fitoplancton

Abstract.- The chain of islands including Desertores, Apiao and Quemchi located in the Inner Sea of Chiloé, in northern Chilean Patagonia (41$44^{\circ} \mathrm{S}$ ), acts as a natural barrier for the flux of water in the north-south direction, influencing exchange and circulation between the northern and southern micro basins. The northern micro basin is mainly characterized by the dominance of surface estuarine waters whereas the southern micro basin is affected by the inflow of Subantarctic Surface and Equatorial Subsurface Waters from the adjacent coastal ocean. This setting determines key differences in the spatial distribution, abundance and size composition of phytoplankton biomass (measured as chlorophylla). These chlorophyll-a qualitative and quantitative differences were evaluated in contrasting seasons twice during 2004 and 2005 surveys (Cruceros de Investigación Marina, CIMAR 10 and 11 Fjords). In both micro basins, physical, chemical and bio-optical data from upper mixed layer water samples were analysed along with 8-days composite satellite images of chlorophyll-a (MODIS-AQUA). The largest difference in environmental heterogeneity between zones was in the concentration of nitrate and silicic acid. In spring the abundance of chlorophyll-a showed high variability in both sub-basins and predominance of micro-phytoplankton. In austral winter the micro-phytoplankton fraction was also dominant in a wide range of environmental with conditions, but closely linked to regions with high silicic acid concentrations. The smaller fractions, however, dominated in a more homogeneous environment characterized by higher nitrate concentration. Although nutrients are not depleted in the study area, the nitrate/silicic acid ratio clearly influenced the autotrophic community abundance, size composition and spatial structure under lower light availability during winter and more complex oceanographic processes during spring.

Key words: Geostatistics, Inner Sea of Chiloé, nutrients, phytoplankton 


\section{INTRODUCTION}

The distribution of planktonic organisms as the central focus of this study is due to the importance of the chemical, physical and biological interactions that affect the marine pelagic ecosystems, generating different spatial patterns in the structure of the phytoplankton community at different scales (Stewart et al. 2000). One of the largest regions of fjords in the world, the Chilean Patagonia, with a total area of 240,000 km (Pantoja et al. 2011), situated on the southwest frontier of the Pacific Ocean at $41.5^{\circ} \mathrm{S}$ (Reloncaví Fjord) to $55.9^{\circ} \mathrm{S}$ (Cape Horn), presents a unique opportunity to study temporal and mesoscale phytoplankton patterns given its potential sensitivity to human pressure and climate change.

In northern Patagonia $\left(41^{\circ}-43^{\circ} \mathrm{S}\right)$, in the Inner Sea of Chiloé, the surface salinity level is influenced by the convergence of ocean waters and freshwaters from local rivers especially in the northern sector (Silva et al. 1995). Described as a transitional marine system (Iriarte et al.
2010), the Inner Sea of Chiloé has micro basins and geographic barriers such as the Desertores/Apiao/ Quemchi island chain (Fig. 1) which hinders the passage of Subantarctic Waters towards the northern zone and stops the Equatorial Subsurface Waters flowing northward of this barrier (Silva et al. 1995, Sievers \& Silva 2008). These geographic characteristics produce long water residence time (Silva \& Palma 2006, Carrasco \& Silva 2010) and affect the tide regimes and their resonance in the northern zone (Cáceres et al. 2003). Here, semidiurnal internal waves enhance vertical mixing, increasing nutrients at the surface through shear instabilities that favour primary production for more extended periods than in classical seasonal systems (Ross et al. 2014). Overall, these estuarine waters are relatively poor in nitrate $\left(\mathrm{NO}_{3}\right)$ and phosphate $\left(\mathrm{PO}_{4}\right)$ but rich in silicic acid $\left(\mathrm{Si}(\mathrm{OH})_{4}\right)$ unlike the southern zone which has more oceanic water influence and therefore more nitrate and phosphate (Silva et al. 1997, 1998; Silva \& Palma 2006, Vargas et al. 2011).

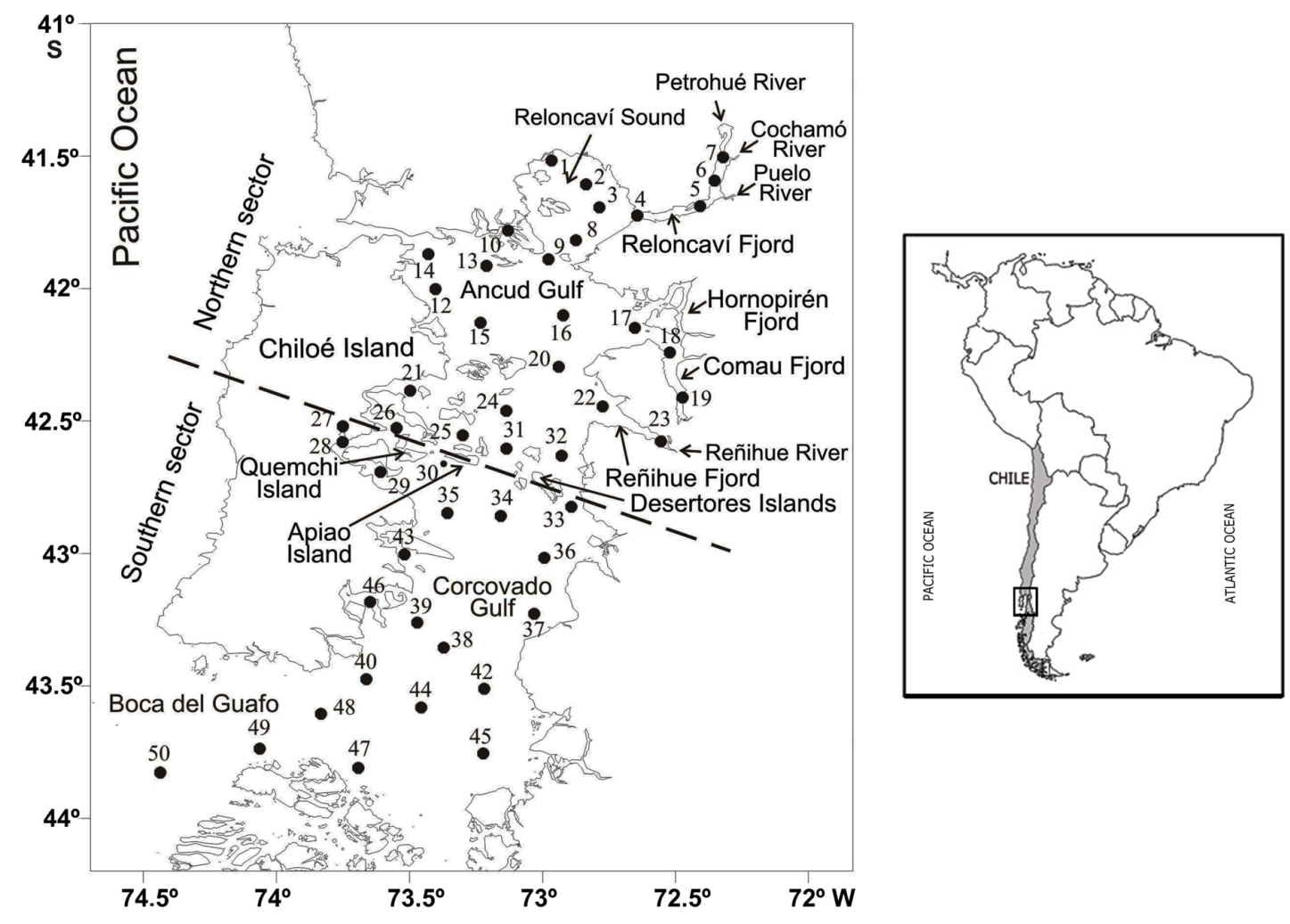

Figure 1. Map of the Inner Sea of Chiloé (ISoCh) and positions of sampling stations during the winter and spring cruises CIM AR 10 and 11 in 2004 and 2005. Dotted line indicates the division between the northern (1-32 stations) and the southern (33-50 stations) sector / Mapa del Mar Interior de Chiloé (ISoCh) y posición de las estaciones de muestreo durante los cruceros de invierno y primavera CIMAR 10 y 11 en 2004 y 2005 . Línea punteada indica la división entre el sector norte (estaciones 1-32) y sur (estaciones 33-50) 
The concentration of in situ chlorophyll- $a(\mathrm{Chl}-a)$ and satellite chlorophyll- $a$ (Chl- $\left.a_{\text {Sat }}\right)$, as an indirect measurement of the biomass of the phytoplankton community (Brewin et al. 2010), has been found to be higher in the northern zone than in the southern part of Northern Patagonia (Pizarro et al. 2000, Ramírez \& Pizarro 2005, Delgado \& Marín 2006, Tello \& Rodríguez-Benito 2009, Montecino et al. 2009). Using MODIS-AQUA satellite images, Lara et al. (2010) observed Chl- $a_{\text {Sat }}$ patches with clearly differentiated spatial temporal patterns. In this last mesoscale study, the spatial dimension of Chl- $a_{\text {Sat }}$ patch sizes was greater than $50 \mathrm{~km}$, attributed to low environmental variability including reduction in light availability in autumn-winter, while during spring-summer the patches were smaller than 30 $\mathrm{km}$ and it was associated with high environmental variability i.e. the presence of oceanic fronts and high frequency of South West winds. Spatially, in the northern zone of the Desertores/Apiao/Quemchi island chain, the structure of Chl- $a_{\text {Sat }}$ patches are smaller and there is more environmental variability while toward the south through the Boca del Guafo (Fig. 1) the larger Chl- $a_{\text {sat }}$ patches (spatial structures) are associated with higher homogeneity.

The latitudinal changes observed in phytoplankton Chl- $a$ concentrations in Chilean Patagonia have been attributed to the availability of nutrients (Aracena et al. 2011), seasonal patterns in the light regimes (González et al. 2010, Paredes \& Montecino 2011), the direction and intensity of winds (Montero et al. 2011) and the stratification of the water column (Lara et al. 2010). The size composition and structure of this autotrophic community is a result of the environmental conditions and depends on biological factors such as reproduction and growth, morphology and different functional types (Reynolds 1988, Alvés de Souza et al. 2008). Spatial and temporal changes in abiotic conditions will have different effects depending on the size of the different thriving phytoplankton components (Marañon et al. 2008). Therefore, in oligotrophic environments with more oceanic influence or in those that are far from the coast, small cell sizes are dominant (Kiørboe 1993, Montecino \& Quiroz 2000, Sabetta et al. 2005, Paredes \& Montecino 2011). By contrast, large cell sizes tend to dominate in well-mixed and turbulent waters such as coastal zones where the concentration of nutrients is higher (Margalef 1978, Sabetta et al. 2005, Marañon 2008, 2009).

Given the underlying oceanographic and latitudinal features in winter and spring in the Inner Sea of Chiloé, it is expected to find peculiar structural patterns in autotrophic communities in accordance with the hypothesis about dissimilarities between environmental heterogeneity north and south of the natural barrier Desertores/Apiao/Quemchi island group. Recognizing which environmental factor (physical, chemical and biooptical) is characteristic of each micro basin in contrasting seasons would enable us to reach a better understanding of the distribution and abundance of in situ Chl-a according to the dominant size fraction, as well as Chl- $a_{\text {Sat }}$ as a proxy for the spatial structures, obtaining greater ecological information on the phytoplankton community of northern Chilean Patagonia.

\section{Materials AND METHODS}

\section{Study ARea AND data COLlection}

The study area was surveyed during CIMAR 10 and 11 Fjord cruises which were carried out in the R/V AGOR Vidal Gormáz: CIMAR 10-1 (August 2004; winter), CIMAR 10-2 (November 2004; spring), CIMAR 11-1 (July 2005; winter) and CIMAR 11-2 (November 2005; spring), covering a total of 50 oceanographic stations during each survey (Fig. 1).

Continuous recording of water temperature and salinity was carried out with a CTD Sea-Bird model SBE 25 and discrete samples of water were collected for analysis of their salinity, dissolved oxygen, nutrients and Chl- $a$, using a Rosette with 24 Niskin bottles. Water samples were taken at standard depths and for this study only the results obtained at surface depths $(0,5$, and $10 \mathrm{~m})$ were used. The CTD data was processed using the Sea-Bird model SBE 25 standard protocol. The salinity sensor was calibrated with the results of the salinity analysis of the discrete samples carried out in an AUTOSAL inductive salinity-meter. Samples of dissolved oxygen were fixed and analyzed on board according to the Winkler method modified by Carpenter (1965). The dissolved oxygen saturation values were calculated based on the Weiss algorithm (1970).

The samples for nutrient analysis were collected in highdensity $(50 \mathrm{ml})$ aseptic polyethylene bottles and stored at $-20^{\circ} \mathrm{C}$. The analysis of nutrients (nitrate+nitrite, phosphate and silicic acid) was carried out with a nutrient autoanalyzer according to Atlas et al. (1971). Since the nitrite content in the austral channels is generally low $(\sim 0-0.3 \mu \mathrm{M})$; the values of nitrate+nitrite can be considered as only nitrate $\left(\mathrm{NO}_{3}^{-}\right)$and they are presented as such. 
Water samples from both Rosette and bucket $(0 \mathrm{~m})$ were processed to measure the total Chl- $a$ (TChl- $a$ ) and size-fractionated Chl- $a$. To obtain these measurements, $250 \mathrm{ml}$ to $500 \mathrm{ml}$ samples were vacuum-filtered directly onto fiberglass filters (Advantec ${ }^{\circledR}$ nominal pore size of $0.7 \mu \mathrm{m}, 25 \mathrm{~mm}$ ). The 3 size fractions of phytoplankton corresponding to microphytoplankton (> $20 \mu \mathrm{m})$, large nannoplankton $(11-20 \mu \mathrm{m})$ and small nannoplankton and picoplankton $(<11 \mu \mathrm{m})$ were obtained by differential filtration of $250-500 \mathrm{ml}$ of the same sample on fiberglass filters, pre-filtering samples through nylon meshes of 20 and $11 \mu \mathrm{m}$ (Montecino et al. 2009, Paredes \& Montecino 2011). The filters were stored in liquid nitrogen until the fluorometric assay, from which the Chl- $a$ was extracted with acetone $(90 \% \mathrm{v} / \mathrm{v})$. Its concentration was quantified in a fluorometer TURNER TD-700 model (Jeffrey et al. 1997). To determine bio-optical parameters, the $250 \mathrm{ml}$ water samples for the absorption of coloured dissolved organic matter (ag) were filtered using $0.7 \mu \mathrm{m}$ precombusted filters and stored in the dark at $4^{\circ} \mathrm{C}$. For further analysis, in the laboratory $100 \mathrm{ml}$ replicates of these samples were filtered through $0.2 \mu \mathrm{m}$ polycarbonate filters prewashed with $3 \mathrm{ml}$ MilliQ ultrapure water. The optical density of the filtrate was measured in a $10 \mathrm{~cm}$ pathlength cuvette with a Shimadzu UV-Visible spectrophotometer between 300-700 nm (+ 0.005) (Strickland \& Parsons 1972) and was recorded using ultrapure MilliQ water as a blank. Expressed absorbance was calculated at $375 \mathrm{~nm}\left(\mathrm{ag}_{\lambda 375}\right)$ after correction for the average absorption spectrum obtained between 710-700 $\mathrm{nm}$ according to Mitchell et al. (2000).

For the same study periods Chl- $a_{\text {Sat }}$ data obtained from satellite images MODIS (Moderate Resolution Imaging Spectroradiometer) aboard the AQUA platform were extracted. Because cloud cover in the study area made satellite images inaccessible on specific days of sampling, the 8- day composite Chl- $a_{\text {Sat }}$ was selected, considering the 3 week duration of the oceanographic cruise for each campaign. The 8-day composite chlorophyll from MODIS for the winter 2004 (August 20 to September 5), spring 2005 (November 8 to 24), winter 2005 (July 12 to 28) and spring 2005 (November 9 to 23), have a spatial resolution of $4 \mathrm{~km}$ at nadir and level L3 processing. All satellite images were obtained from the NASA website ${ }^{1}$. The Chl- $a_{\text {Sat }}$ product was obtained using the algorithm OC3 MODIS (O'Reilly et al. 2000). Collecting data from the Chl- $a_{\text {Sat }}$ satellite images was performed in the Environment for Visualizing Images, 2005 (ENVI) version 4.5, where the images were processed by an equidistant cylindrical projection. Subsequently, by dynamic interactive IDL language the Chl- $a_{\text {Sat }}$ values were extracted for all pixels in each of the zones as proposed by the Canty (2006) algorithm. In order to avoid anthropogenic effects, masking substances (detritus, dissolved organic matter, coloured substances), and to reduce the noise and anomalies inherent in coastal ocean color data, the information from MODIS images located within $4 \mathrm{~km}$ of the coast were excluded from the analysis.

\section{Data anAlysis}

\section{Data ObTained IN SITU}

To evaluate differences between abiotic factors (temperature, salinity, dissolved oxygen, silicic acid, nitrate, phosphate and coloured organic matter, $\mathrm{ag}_{\lambda 375}$, and phytoplankton (TChl- $a$ and Chl- $a$ fractionated by size) between northern and southern sectors of the Desertores/Apiao/Quemchi island group and both winters and springs, two way Analysis of Variance was used. Beforehand, a normality test (Kolmogorov-Smirnov test) was done and homoscedasticity (Bartlett Docimo) of the response variable (integrated from 0 to $10 \mathrm{~m}$ ) was evaluated. Data were normalized using $\log (\mathrm{x}+1)$.

In addition, a multiple regression with continuous variables and the Forward Stepwise method was used after establishing independence and identical distribution of errors by means of the Durbin-Watson statistic, and transformed by Box-Cox, through the STATISTICA 6.0 package.

\section{Spatial analysis of CHL- $a_{\mathrm{S}_{\mathrm{A}}}$}

A semivariogram function was used to carry out structural analysis of spatial data of Chl- $a_{\text {Sat }}$ obtained from satellite images (Equation 1).

$$
\gamma(h)=\frac{1}{2} \sum_{i=1}^{n}\left\{Z\left(x_{i}\right)-Z\left(x_{i}+h\right)\right\}^{2}
$$

where $\gamma(h)$ is the semivariance of $Z$ variable distance $h, Z$ $\left(x_{i}\right)$ is the value of the variable examined in the $\left(x_{i}\right), Z\left(x_{i}+\right.$ $h)$ is the value of the variable examined in the $\left(x_{i}+h\right)$ position, while $\eta$ is the number of pairs of samples spaced by distance $h$ (Burroughs 1996) samples. This analysis characterizes the potential spatial dependence of Chl- $a_{\text {Sat }}$ at different spatial scales (Miranda-Salas \& Condal 2003, Lara et al. 2010, Gerstmann et al. 2010). The spatial

${ }^{1}<$ http://oceancolor.gsfc.nasa.gov/cgi//3> 
dependence between the values of Chl- $a_{\text {Sat }}$ analyzed in this study was estimated with variograms at intervals of 5 $\mathrm{km}$ for each image and a distance ' $\mathrm{h}$ ' of $50 \mathrm{~km}$. Variogram analysis was performed with GS+ (Geostatistics for the Environmental Sciences) software, version 7.02.

To quantify the spatial structure of chlorophyll- $a$ concentration, we used spherical models since they adapt to the main properties of the experimental variograms (Garrigues et al. 2006). The linear behaviour and the origin continuity diminish the noise with the semivariance rising smoothly to a stable and fixed range (Broitman \& Kinlan 2006).

\section{ANALYSIS OF ENVIRONMENTAL FACTORS}

For the definition of the northern and southern sectors (defined $a$ priori) and for the seasons (winter-spring), multivariate analyses were used. The relationship between fields of study and environmental variables were ordered by Non-Metric Multi-Dimensional Scaling (NMDS) Analysis. The differences between the sectors were evaluated through analysis of similarity ANOSIM (Clarke \& Gorley 2006) considering 999 permutations of the similarity matrix. Furthermore, the SIMPER analysis was used to quantify the average distance from the set of abiotic factors and to identify the physical, chemical and optical variables that contributed (in \%) to differentiation (dissimilarity) between groups (geographic areas). The techniques described above were carried out with the software PRIMER $6^{3}$.

\section{ReSUlts}

\section{ENVIRONMENTAL FACTORS}

The ordination analysis shows that the physical, chemical and bio-optical conditions (i.e., $\operatorname{ag}_{\lambda 375}$ ) obtained during CIMAR cruises exhibited good graphic representations according to Clarke \& Warwick (2001), with low stress values (no greater than 0.12) found only during winter 2004 (Fig. 2). The average spatial range distances in the northern sector shows a greater spread of abiotic factors (heterogeneity min and max \% values from 21.66 to 117.22 ) compared to the southern sector (15.55 to 28.4) (Table 1), where the distances of the factors were generally significantly lower $(P<0.05)$, and not different between north and south in the winter of 2005 (Table 1 and Fig. 3). The variables with the greatest differences between sectors were mainly nutrients, specifically nitrate and silicic acid (Fig. 3). Nitrate contributed with the highest percentages of dissimilarity between sectors, over $32 \%$ of the total during the 4 cruises, except for winter 2005, where the contribution of silicic acid was higher $(85 \%)$. In general, nitrate and silicic acid together were the variables contributing more than $70 \%$ of the dissimilarity for both sectors. Salinity was the smallest contributor (10-20\%) and was relevant only during springtime (Fig. 4).

Table 1. Mean values for the winter and spring in 2004 and 2005 of environmental heterogeneity (\%) measured as the average Euclidean distance of the dispersion of the set of abiotic factors and their significance according to the ANOSIM test (*: significant differences exist). $\mathbf{N}=$ north; $\mathbf{S}=$ south / Valores de la heterogeneidad ambiental (\%) medida como distancia euclidiana promedio de la dispersión del conjunto de factores abióticos y su significancia según la prueba ANOSIM (*: existen diferencias significativas). $\mathrm{N}=$ norte; $\mathrm{S}=$ sur

\begin{tabular}{|c|c|c|c|c|c|c|c|c|}
\hline \multirow[b]{2}{*}{ Time } & \multicolumn{4}{|c|}{2004} & \multicolumn{4}{|c|}{2005} \\
\hline & \multicolumn{2}{|c|}{ winter } & \multicolumn{2}{|c|}{ spring } & \multicolumn{2}{|c|}{ winter } & \multicolumn{2}{|c|}{ spring } \\
\hline Space & $\mathrm{N}$ & $\mathrm{S}$ & $\mathrm{N}$ & $\mathrm{S}$ & $\mathrm{N}$ & $\mathrm{S}$ & $\mathrm{N}$ & $\mathrm{S}$ \\
\hline Heterogeneity (\%) & 82.19 & 25.6 & 117.22 & 28.4 & 21.66 & 15.55 & 68.19 & 18.55 \\
\hline $\begin{array}{l}\text { ANOSIM } \\
\mathrm{R}+\text { significance level }(P)^{*}\end{array}$ & 0.084 & $<0.05^{*}$ & 0.308 & $<0.05^{*}$ & 0.068 & $>0.05$ & 0.135 & $<0.05^{*}$ \\
\hline
\end{tabular}

${ }^{2}$ Insightful Corp., Washington, USA, 1990.

${ }^{3}$ Bob Clarke and Ray Gorley. Plymouth Marine Laboratory (PML), United Kingdom 


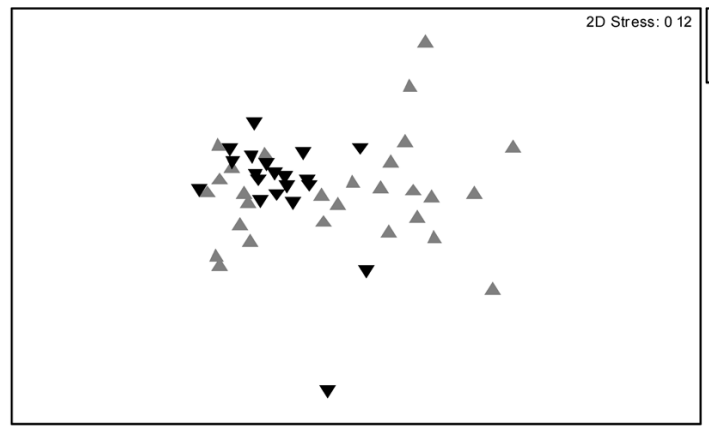

Winter 2005

ANOSIM $=$ Global R: 0.068 ; Level significance $(P):<0.05^{*}$

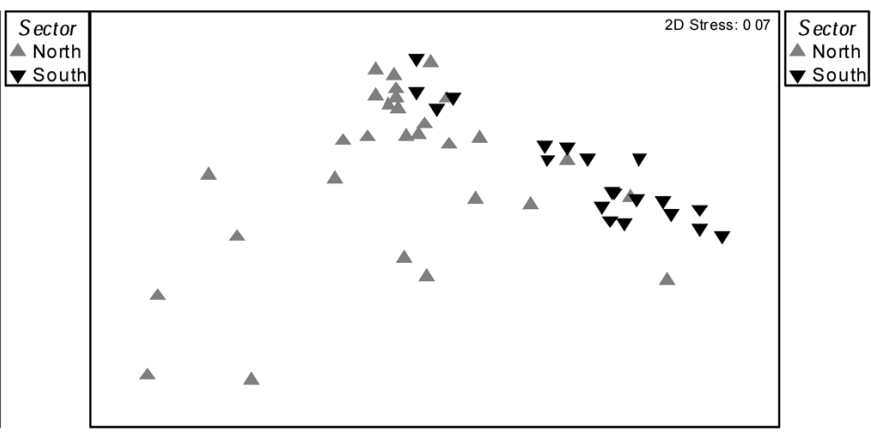

Spring 2005

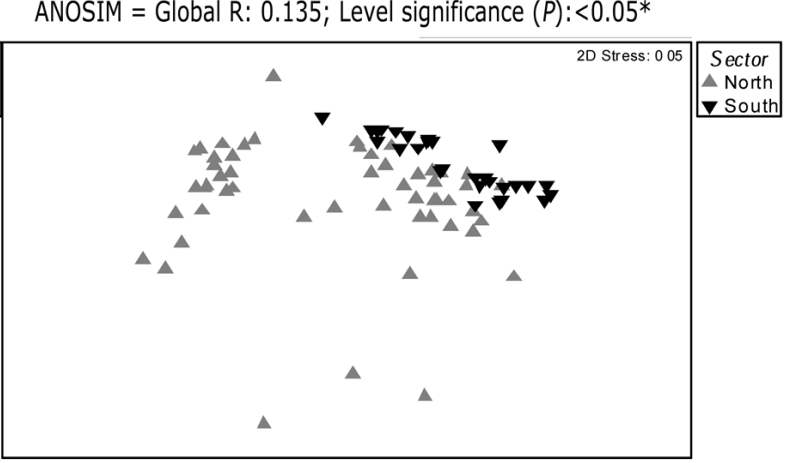

Figure 2. Sorting of the abiotic variables in the ISoCh* during CIMAR 10 and 11 Fjords (winter and spring 2004-2005) between the northern and the southern sector, obtained through nonmetric multivariate multidimensional scaling analysis (NMDS). Details of the data treatment and results of ANOSIM analysis are given, (*) significant differences exist / Ordenación de las variables abióticas en el ISoCh* durante los Cruceros CIMAR 10 y 11 Fiordos (invierno y primavera 2004-2005) entre los sectores norte y sur, obtenidos mediante análisis multivariado de escalamiento no métrico multidimensional (NMDS). Se detallan los tratamiento de los datos y los resultados del análisis ANOSIM, $\left({ }^{*}\right)$ existen diferencias significativas

\section{Phytoplankton size fractions and total Chl-a ABUNDANCES}

The concentration of TChl- $a$ presented a seasonal pattern both in the northern as well as in the southern sectors of the Inner Sea of Chiloé (thereafter referred to as ISoCh*). During both winter seasons, the northern and southern sectors showed significant differences $(P<0.05)$ in the abundance of TChl- $a$. The phytoplankton concentration of the large fraction $(>20 \mu \mathrm{m})$ in the northern sector was significantly higher during winter, while in the southern sector the small fraction $(<11 \mu \mathrm{m})$ was significantly higher $(P<0.05)$ during this season. Moreover, higher concentrations of TChl- $a$ were recorded during the 2 campaigns in 2004 compared to what was observed during the two campaigns in 2005 (Table 2).

\section{ASSOCIATION OF PHYSICAL AND CHEMICAL CONDITIONS WITH THE CONCENTRATION OF TCHL-a}

The concentration of TChl- $a$ during the winter cruises presents an inverse relationship $(P<0.005)$ with nitrate in the northern zone (Beta coeff.: $-0.69 ; \mathrm{r}^{2}: 0.66$ ) and southern zone (Beta coeff.: $\left.-0,45 ; r^{2}: 0.60\right)$ of the ISoCh. In the case of the relationship of TChl- $a$ with silicic acid within the same season, this negative relationship was only found for the northern zone (Beta coeff.: $-0,25 ; \mathrm{r}^{2}$ : 0.66). On the other hand during both springs, there is a positive relationship of TChl- $a$ with oceanographic factors such as salinity in the northern zone (Beta coeff.: 0.49; $\mathrm{r}^{2}$ : 0.20 ) and with temperature (Beta coeff.: $0.51 ; r^{2}: 0.68$ ) in the southern zone. 


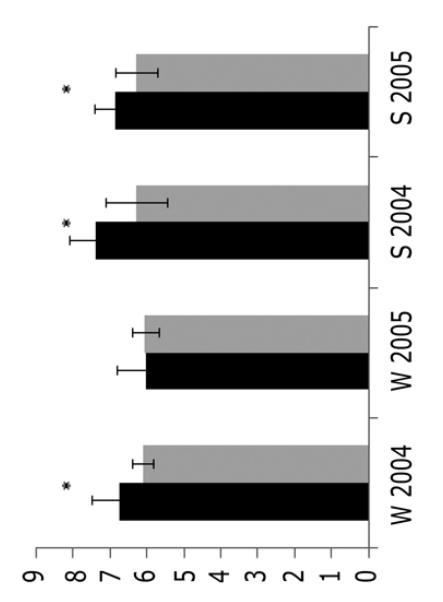

(ז.า ךய) чә6/хо

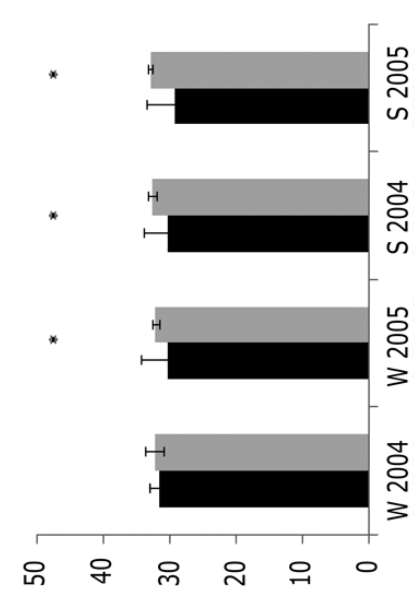

(nsd) Rํ!u!leS

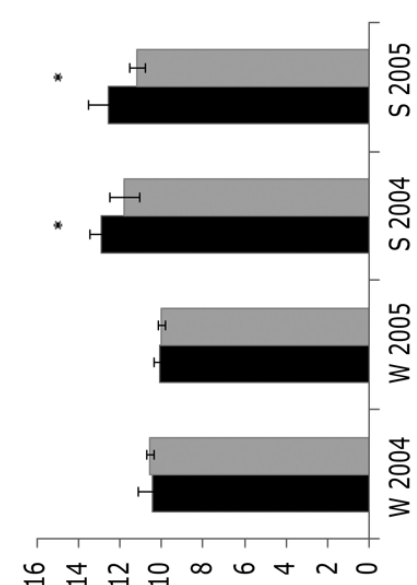

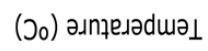

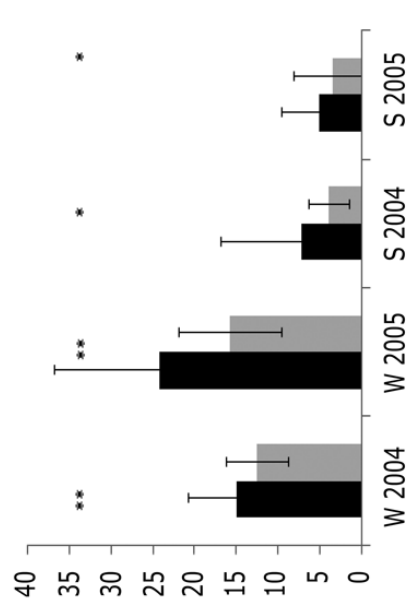

(uri) p!ฺอ ग!ฺ!!!

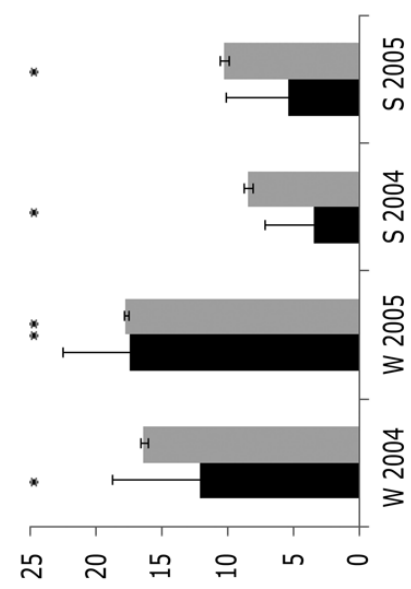

(uri) әұาג?!N

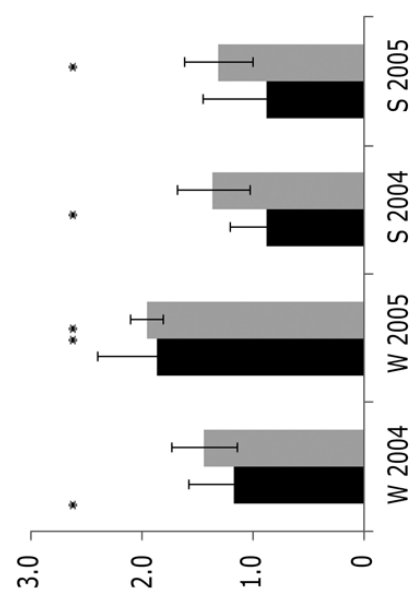

(uri) әңецdsoud

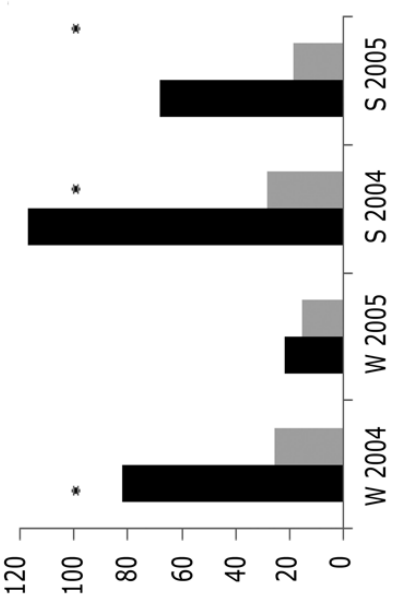

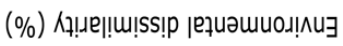

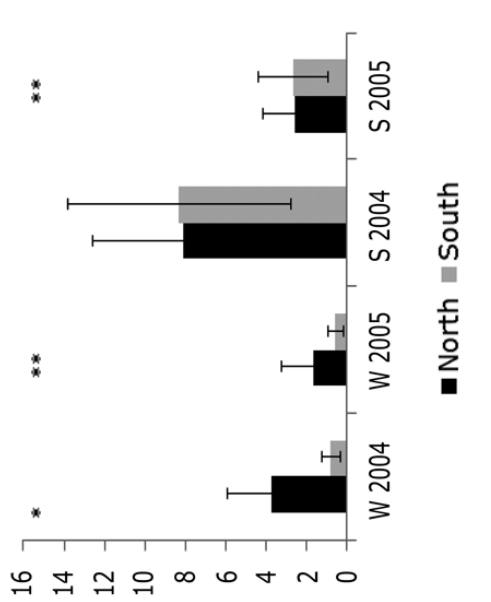

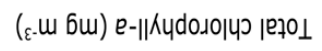

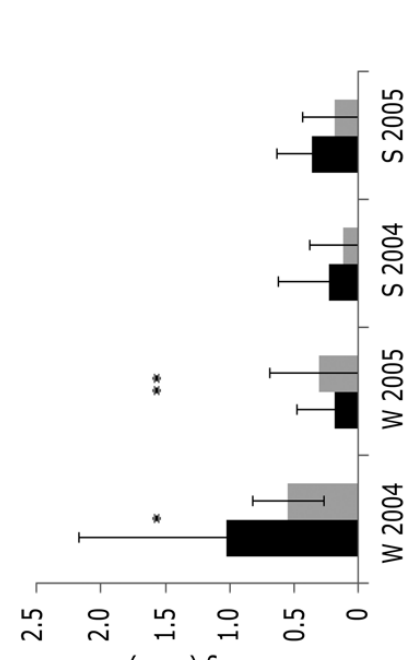

$(s \angle \varepsilon \gamma)$ be

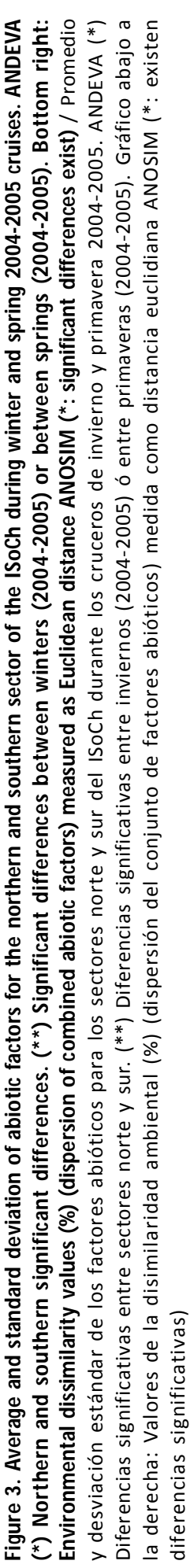




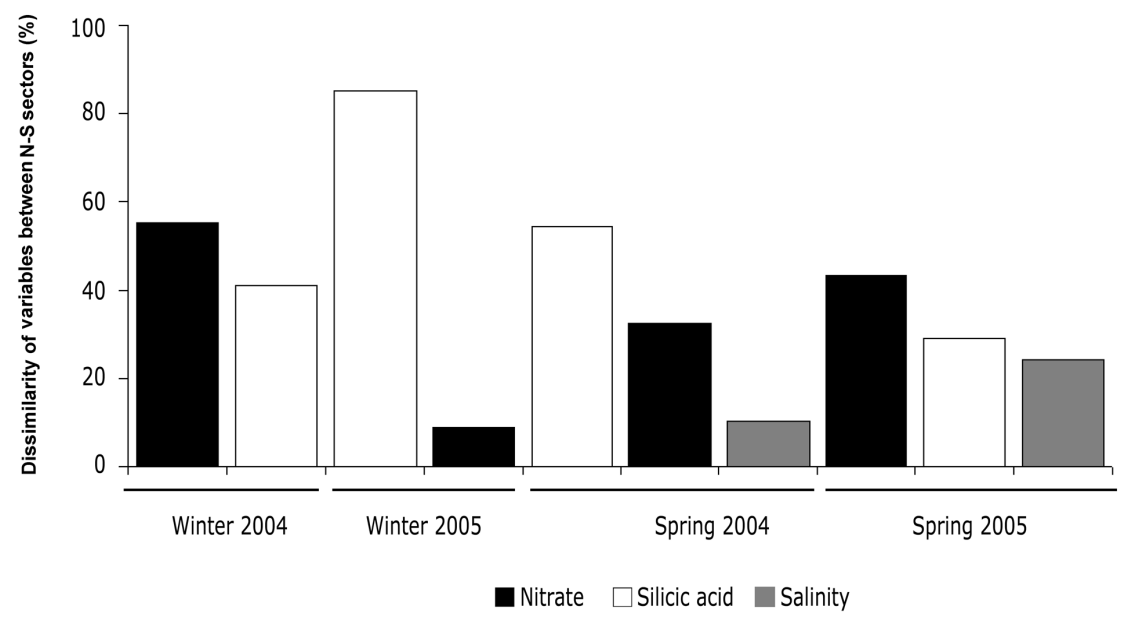

Figure 4. Contribution in percentage (\%) of dissimilar variables between the northern and southern sectors of the four cruises analyzed (winter and spring 2004-2005) according to SIMPER analysis results / Contribución en porcentaje (\%) de las variables disimiles entre los sectores norte y sur de los cuatro cruceros analizados (invierno y primavera 20042005), de acuerdo con los resultados obtenidos de análisis SIMPER

Table 2. Summary of descriptive statistics (one-way ANOVA, $F$ and $P$ values) in right columns of the abundance of phytoplankton total chlorophyll$a$ and of the three size fractions between the northern and southern sector of the ISoCh during winter and spring cruises in 2004-2005. Percent (\%) fraction sizes according to north-south sectors and time of year are also indicated. * Indicate statistically significant differences / Resumen de estadística descriptiva (ANDEVA de una vía, valores F y P) de la abundancia fitoplanctónica de la clorofila-a total y por tres fracciones de tamaño entre los sectores norte y sur del ISoCh durante los cruceros de invierno y primavera 2004-2005. (\%) Porcentaje de la fracción de tamaños de acuerdo a sector y época del año. ${ }^{*}$ Indica diferencias estadísticamente significativas

\begin{tabular}{|c|c|c|c|c|c|c|}
\hline & North & $\begin{array}{l}\text { Percentage } \\
\text { of TChl- } a\end{array}$ & South & $\begin{array}{l}\text { Percentage } \\
\text { of TChl- } a\end{array}$ & & \\
\hline & $\mathrm{mg} \mathrm{m}^{-3}$ & $\%$ & $\mathrm{mg} \mathrm{m}^{-3}$ & $\%$ & $\mathrm{~F}$ & $P$ \\
\hline \multicolumn{7}{|c|}{ Total chlorophyll-a (TChl- $a$ ) } \\
\hline Winter 2004 & $3.70 \pm 2.27$ & & $0.77 \pm 0.47$ & & 13.87 & $<0.05^{*}$ \\
\hline Spring 2004 & $8.05 \pm 4.60$ & & $8.31 \pm 5.51$ & & 0.02 & 0.87 \\
\hline Winter 2005 & $1.67 \pm 1.57$ & & $0.55 \pm 0.40$ & & 4.41 & $<0.05^{*}$ \\
\hline Spring 2005 & $2.55 \pm 1.63$ & & $2.66 \pm 1.72$ & & 0.08 & 0.78 \\
\hline \multicolumn{7}{|c|}{ Large fraction (microphytoplankton) } \\
\hline Winter 2004 & $2.67 \pm 2.30$ & 72.1 & $0.32 \pm 0.30$ & 42.6 & 14.27 & $<0.05^{*}$ \\
\hline Spring 2004 & $6.34 \pm 2.40$ & 78.7 & $6.46 \pm 2.00$ & 77.8 & 0.42 & $>0.05$ \\
\hline Winter 2005 & $0.81 \pm 0.90$ & 48.4 & $0.03 \pm 0.03$ & 5.3 & 5.93 & $<0.05^{*}$ \\
\hline Spring 2005 & $1.44 \pm 1.10$ & 56.3 & $1.79 \pm 1.70$ & 67.4 & 0.57 & $>0.05$ \\
\hline \multicolumn{7}{|c|}{ Medium fraction (large nannophytoplankton) } \\
\hline Winter 2004 & $0.25 \pm 0.47$ & 6.6 & $0.05 \pm 0.06$ & 6.9 & 2.28 & $>0.05$ \\
\hline Spring 2004 & $0.05 \pm 0.04$ & 0.6 & $0.24 \pm 0.31$ & 2.8 & 0.98 & $>0.05$ \\
\hline Winter 2005 & $0.33 \pm 0.38$ & 19.5 & $0.09 \pm 0.19$ & 15.7 & 3.15 & $>0.05$ \\
\hline Spring 2005 & $0.42 \pm 0.58$ & 16.5 & $0.37 \pm 0.24$ & 13.9 & 0.04 & $>0.05$ \\
\hline \multicolumn{7}{|c|}{$\begin{array}{l}\text { Small fraction (small } \\
\text { nannophytoplankton and picophytoplankton) }\end{array}$} \\
\hline Winter 2004 & $0.78 \pm 0.93$ & 21.2 & $0.39 \pm 0.20$ & 50.4 & 2.43 & $>0.05$ \\
\hline Spring 2004 & $1.66 \pm 0.43$ & 20.6 & $1.61 \pm 0.45$ & 19.4 & 1.19 & $>0.05$ \\
\hline Winter 2005 & $0.54 \pm 0.43$ & 32.2 & $0.43 \pm 0.24$ & 78.9 & 0.44 & $>0.05$ \\
\hline Spring 2005 & $0.69 \pm 0.51$ & 27.2 & $0.49 \pm 0.22$ & 18.6 & 1.33 & $>0.05$ \\
\hline
\end{tabular}




\section{Spatial analysis of CHL- $\boldsymbol{a}_{\mathrm{S}}$}

Chl- $a_{\text {Sat }}$ abundance results show a different spatial and temporal pattern in both ISoCh zones (Table 3). In the northern zone during the two spring periods the maximum Chl- $a_{\text {Sat }}$ mean values were recorded $\left(7.99 \pm 2.29 \mathrm{mg} \mathrm{m}^{-3}\right.$; $7.24 \pm 2.23 \mathrm{mg} \mathrm{m}^{-3}$ respectively) and higher than those during winter periods $\left(1.99 \pm 2.7 \mathrm{mg} \mathrm{m}^{-3} ; 2.59 \pm 2.29 \mathrm{mg} \mathrm{m}^{-3}\right.$, respectively). In the southern zone the pattern was similar, reaching maximum values of $6.60 \pm 1.99 \mathrm{mg} \mathrm{m}^{-3} ; 6.91 \pm 2.13$ $\mathrm{mg} \mathrm{m}^{-3}$ during spring periods, significantly higher than those during winter periods $\left(0.81 \pm 1.28 \mathrm{mg} \mathrm{m}^{-3} ; 0.87 \pm\right.$ $1.25 \mathrm{mg} \mathrm{m}^{-3}$ ). The greatest spatial Chl- $a_{\text {Sat }}$ variability (Table 3 ) was observed in the northern zone during spring season (nugget: 3.60 and 4.56) associated with smaller size spatial structures or patch sizes $(39.2 \pm 4.0 \mathrm{~km}$ and $20.1 \pm 4.0 \mathrm{~km})$, while less heterogeneity (nugget 0.17 and 0.75 ) was associated during both winter periods to larger spatial structures $(48.2 \pm 8.0 \mathrm{~km}$ and $52.7 \pm 5.0 \mathrm{~km})$.

In the southern zone, smaller Chl- $a_{\text {Sat }}$ spatial structures $(34.0 \pm 4.0 \mathrm{~km} ; 37.8 \pm 6.15 \mathrm{~km})$ associated with greater spatial heterogeneity (nugget: 3.40 and 2.65 ) were obtained during spring seasons (2004-2005). During both winters lower spatial heterogeneity was associated with larger spatial structures $(56.2 \pm 12.0 \mathrm{~km} ; 43.0 \pm 9.0 \mathrm{~km})($ Table 3$)$.

Despite similar temporal patterns in in situ Chl- $a$ and Chl- $a_{\text {Sat }}$, when comparing average values shown in Tables 2 and 3 , there were some differences between the 8-day composite satellite data and those obtained in predetermined oceanographic stations during 2004-2005 (i.e., in spring: 7.99-7.24 $\mathrm{m}^{-3} \mathrm{Chl}-a_{\mathrm{Sat}}$ in the northern zone, $6.60-6.91 \mathrm{mg} \mathrm{m}^{-3} \mathrm{Chl}-a_{\mathrm{Sat}}$ in the southern zone compared with $8.05-2.55 \mathrm{mg} \mathrm{m}^{-3}$ TChl- $a$ in the northern zone, 8.31$2.66 \mathrm{mg} \mathrm{m}^{-3}$ TChl- $a$ in the southern zone).

\section{Discussion}

The phytoplankton communities in the ISoCh are characterized by a highly seasonal temperate zone pattern (Parsons et al. 1977, Ramirez \& Pizarro 2005, Iriarte et al. 2007, Montecino et al. 2009, Aracena et al. 2011, Montero et al. 2011, Rebolledo et al. 2011). The temporal variations in both Chl- $a_{\text {Sat }}$ and TChl- $a$, showed the same seasonal trends, although average monthly values of Chl- $a_{\text {Sat }}$ were relatively higher than those TChl- $a$ recorded in situ. Nevertheless, maximal temporal variability for Chl- $a_{\mathrm{Sat}}$ is within the range of values described by SeaWiFS and MODIS satellite images for the Inner Sea of Chiloé (Delgado \& Marín 2006, Iriarte et al. 2007, Tello \& Rodríguez-Benito 2009, Lara et al. 2010). The difference between the average Chl- $a_{\text {Sat }}$ and in situ TChl- $a$ (Table 2 and 3) that was observed in the northern zone could be related to the greater dissimilarity (heterogeneity) of the physical, chemical and optical factors measured in this zone (Fig. 2). The northern zone has a greater continental contribution compared to the southern zone, which has more homogeneous abiotic environmental conditions (Fig. 3). Moreover, the higher spatial resolution of satellite images $(4 \mathrm{~km})$ coupled with the L3 adjustments derived from MODIS based in case I water optical properties

Table 3. Summary of the spatial statistical results of heterogeneity measured as initial variance, nugget, patch size and average $\mathrm{Chl}-\mathrm{a}_{\text {sat }}$ for the northern (N) and southern (S) sectors of the ISoCh during the winter and spring cruises (20042005) / Resumen de los resultados del análisis de estadística espacial de la heterogeneidad medida como variación inicial, pepita, tamaño del parche y el promedio de Chl- $a_{\text {Sat }}$ para los sectores norte (N) y sur (S) del ISoCh durante los cruceros de invierno y primavera (2004-2005)

\begin{tabular}{|c|c|c|c|c|c|c|c|c|}
\hline & \multirow{2}{*}{\multicolumn{2}{|c|}{$\begin{array}{l}\text { Chl- } a_{\text {sat }} \\
\left(\mathrm{mg} \mathrm{m}^{-3}\right)\end{array}$}} & \multicolumn{4}{|c|}{ Heterogeneity } & \multirow{2}{*}{\multicolumn{2}{|c|}{$\begin{array}{l}\text { Patch Size } \\
\quad(\mathrm{km})\end{array}$}} \\
\hline & & & \multicolumn{2}{|c|}{ initial variance } & \multicolumn{2}{|c|}{ nugget } & & \\
\hline & $\mathrm{N}$ & $\mathrm{S}$ & $\mathrm{N}$ & $\mathrm{S}$ & $\mathrm{N}$ & $\mathrm{S}$ & $\mathrm{N}$ & $\mathrm{S}$ \\
\hline & \multicolumn{2}{|c|}{ Mean $\pm \sigma$} & \multicolumn{2}{|c|}{ Mean $\pm \sigma$} & & & \multicolumn{2}{|c|}{ Mean $\pm \sigma$} \\
\hline 2004 & & & & & & & & \\
\hline winter & $1.99 \pm 2.70$ & $0.81 \pm 1.28$ & $1.99 \pm 2.70$ & $0.81 \pm 1.28$ & 0.17 & 0.12 & $48.2 \pm 8.0$ & $56.2 \pm 12.0$ \\
\hline spring & $7.99 \pm 2.29$ & $6.60 \pm 1.99$ & $7.99 \pm 2.29$ & $6.60 \pm 1.99$ & 3.60 & 3.40 & $39.2 \pm 4.0$ & $34.0 \pm .0$ \\
\hline \multicolumn{9}{|l|}{2005} \\
\hline winter & $2.59 \pm 2.29$ & $0.87 \pm 1.25$ & $2.59 \pm 2.29$ & $0.87 \pm 1.25$ & 0.75 & 1.20 & $52.7 \pm 5.0$ & $43.0 \pm 9.0$ \\
\hline spring & $7.24 \pm 2.23$ & $6.91 \pm 2.13$ & $7.24 \pm 2.23$ & $6.91 \pm 2.13$ & 4.56 & 2.65 & $20.1 \pm 4.0$ & $37.8 \pm 6.1$ \\
\hline
\end{tabular}


(Moses et al. 2009), and also the 8 days average values could help to explain the differences that were found between Chl- $a_{\text {Sat }}$ data and those obtained in one day in predetermined oceanographic stations $(n=50)$.

In addition, it should be noted that the ISoCh is no exception in terms of strong inter-annual changes in seasonal weather conditions (i.e., solar radiation, wind and precipitation; Pickard 1970, Castillo et al. 2012) that were reflected in the intra-seasonal variability concentration of Chl- $a$ presented in the winter and spring seasons in 2004-2005.

The differences in the concentration of Chl- $a$ between the north and south zones in the ISoCh separated by the Desertores/Apiao/Quemchi island group reported by Pizarro et al. (2000), Ramírez \& Pizarro (2005), Delgado \& Marín (2006), Tello \& Rodríguez-Benito (2009) and Montecino et al. (2009) were consistent with the patterns identified in this study, where, during the winter period, higher concentrations of TChl- $a$ were observed in the northern zone (Reloncaví Sound-Gulf of Ancud) compared with the southern zone (Corcovado Gulf-Boca del Guafo). The largest fraction of the phytoplankton dominated in the northern zone, while the southern zone was dominated by the smallest fraction, coinciding with the results of Paredes \& Montecino (2011), who point out that TChl- $a$ depends on the size of the dominant fraction, fully dominating the small fraction of phytoplankton in low values of TChl- $a$ (winter 2004-2005, 50-79\%, Table 2). Iriarte et al. (2014) include spatial variability in nutrient concentrations, which together with the strong light attenuation induced by glacier-derived freshwater may further explain carbon fluxes and the spatial patterns in primary productivity and phytoplankton biomass.

Although the northern zone has the influence of the major rivers of the area i.e., Petrohué $\left(278 \mathrm{~m}^{3} \mathrm{~s}^{-1}\right)$, Puelo $\left(670 \mathrm{~m}^{3} \mathrm{~s}^{-1}\right)$ (Dávila et al. 2002, Calvete \& Sobarzo 2011, Pantoja et al. 2011, Silva \& Vargas 2014), the salinity values during the winter 2004 were the same as those of the southern sector (Corcovado Gulf-Boca del Guafo) (Fig. 3 ). The major differences between the 2 geographic zones during the contrasting seasons are seen in nitrate and silicic acid, while salinity contributes to this differentiation only during spring (Fig. 3). In these results, the narrow passages formed by the presence of the Desertores/ Apiao/Quemchi island group, are highlighted as an important bathymetric barrier to the water flow that favours the generation of different abiotic characteristics located north and south of this barrier. Thus the southern zone is characterized by its connection with the Boca del Guafo, a strong influence of the oceanic region in which the chemical properties of Subantarctic Waters are maintained with the high concentration of nitrate and phosphate and low silicic acid, while the northern zone is rich in silicic acid from inland waters (Silva et al. 1997, 1998; Silva \& Guzmán 2006, Silva \& Palma 2006, Carrasco \& Silva 2010, Vargas et al. 2011, Iriarte et al. 2014). These environmental heterogeneity differences generate mesoscale changes in the autotrophic community between the two sectors during the winter season, showing a TChl- $a$ dominance of the small fraction of phytoplankton in the southern sector and TChl-a dominance of the microphytoplankton in the northern sector. Although the chemical and physical properties differ during the contrasting seasons analyzed in this study, in both spring (2004-2005) seasons, the phytoplankton community, expressed as TChl- $a$ and fractionated by size, showed a similar feature in the north and south of Desertores/Apiao/Quemchi Passages. This is a dominant contribution of the microphytoplankton fraction (> $20 \mu \mathrm{m}$ ) (Table 2) in both sectors. Furthermore, the approaches used by Paredes et al. (2014) explain these patterns of microphytoplankton groups and their composition either at regional or at smaller spatial scales.

Several authors have reported on the dominance of diatom r-strategists in the Chilean fjords region in early spring (Avaria et al. 1997, Alvés de Souza et al. 2008, Valenzuela \& Avaria 2009), which according to Margalef (1958) is characteristic of a productive community that is maintained in the early stages of population succession. In conjunction, this larger size fraction was dominant in the northern sector during both seasons (winter and spring) that were analysed and is similar to those patterns found by other studies in the Patagonian fjords, where the largest fraction of phytoplankton dominates in transitional zones (estuarine-ocean) (Uribe 1992, Iriarte et al. 1993, 2001, 2007; Torres et al. 2011). Moreover, it has been reported that the phytoplankton community of Reloncaví Sound (Fig. 1) is theoretically more likely to restart production processes in the short term (Ramirez \& Pizarro 2005).

Field studies and laboratory microcosms indicate that the limiting diatom growth factor (considering them to be the dominant component of microphytoplankton) is the silicic acid (Egge \& Aksnes 1992, Hamm et al. 2003, Sánchez et al. 2003, González et al. 2010, Torres et al. 2011) where 2 $\mu \mathrm{M}$ is the minimum concentration required for the development of their populations (Egge \& Aksnes 1992). By increasing the concentration of silicic acid, the diatoms 
displace other species, increasing their rate of growth and reproduction and decreasing this resource (Egge \& Aksnes 1992). Moreover, it has been reported that diatoms require lower concentrations of nitrate and that this decrease occurs with increasing phytoplankton body size (Iriarte $e t$ al. 2005). Additionally they exhibit other advantages such as faster reproduction in regions of high turbulence (Montecino et al. 2006) through higher growth efficiency under low light conditions (Pizarro et al. 2000, Goldman \& Mc-Gillicuddy 2003). Several studies indicate that phytoplankton assemblages in Chilean Patagonian coastal waters are adapted to low light conditions, because of the extensive cloud cover present in the region for most of the year (Barbieri et al. 2001, Iriarte et al. 2007).

Confirming previous studies, with the results obtained in this study, we proved that changes in the latitudinal patterns obey physical and chemical forces and where limited light during winter is counteracted by high concentrations of silicic acid supplied by inland waters (northern sector) and may be offset with a threshold concentration of this nutrient. Also, with heterogeneous ambient conditions of the surface water layers, the condition for autotrophic growth under light shortage is enhanced. Moreover, the minimum reported concentration of silicic acid during the entire study period of $3.5 \mu \mathrm{M}$, as a bottom up factor exceeds the minimum concentration reported by Egge \& Aksnes (1992). Therefore, it can be inferred that as the summer approaches, increasing solar radiation, under no nutrient limitation, and changes in wind direction modulate the distribution and abundance of phytoplankton in the north-south zones of the ISoCh. Regardless of the differences in nutrient concentrations that were established between the two zones, Chl-a concentration behave similarly in both sectors, so that the abundance of TChl- $a$ responds primarily to favourable spring time processes shown by the higher temperature of the water column (Fig. 3). This study emphasizes that the robustness of the factors that modulate the growth of phytoplankton depend on the season.

Studies in the ISoCh highlight the influence of temperature and nutrients, particularly nitrate and silicate, on phytoplankton composition and abundance (Avaria et al. 1997, Pizarro et al. 2000, Ramirez \& Pizarro 2005, Montecino et at. 2006). In our study, the abundance of TChl- $a$ exhibited an inverse and seasonal relationship with the concentration of nitrate and silicic acid. This reveals a direct relationship between the consumption of nutrients and phytoplankton abundance, registering lower availability of these nutrients in the spring compared to the winter season, where concentrations of TChl- $a$ were significantly lower $(P<0.005)$ (Table 2$)$. A direct relationship between geographic areas and Chl- $a$ patch size was evident and significant responses were obtained among contrasting conditions, due to seasonality: large and more homogenous patch sizes during winter and smaller patch sizes with higher heterogeneity during spring. This could be related to the complex dynamics of non-lineal responses of natural populations (Beckas \& Arndt 2013) to physical processes (i.e., lateral stirring and mixing) that drive spatial dynamics at the mesoscale (Martin 2003), also shown by Lara et al. (2010) in the ISoCh. Despite north-south interannual nutrient differences during seasons, the phytoplankton community abundance patterns do respond to seasonality factors, underscoring the relevance of nutrients under lower light availability during winter and more complex oceanographic processes during spring. We suggest that future validation of satellite products in optically complex coastal waters can increase spatial and temporal analysis of phytoplankton communities change especially under the influence of long-term anthropogenic effects.

\section{ACKNOWLEDGMENTS}

We acknowledge the National Oceanographic Committee for the funding of the 04-09 C10F-CONA, CONA-C11F C10F 04-18 05-09 and CONA-C11F 05-18 CIMAR projects and the CONA Scholarship 2010 which allowed V. Martinez to finish her master's thesis. C. Lara was supported by the Millennium Nucleus Center for the Study of Multiple-drivers on Marine Socio-Ecological Systems (MUSELS), MINECON NC120086. We are grateful of M.A. Paredes, Bernardo R. Broitman and Moises Aguilera for suggestions. We thank the Hydrographic and Oceanographic Service of the Chilean Navy, SHOA, and the crew, officers and commanders-inchief of AGOR 'Vidal Gormaz' and especially researchers Claudio Barría, Cristián González and Paola Reinoso for their participation and collaboration during CIMAR cruises.

\section{LITERATURE CITED}

Alvés de Souza C, M González \& JL Iriarte. 2008. Functional groups in marine phytoplankton assemblages dominated by diatoms in fjords of southern Chile. Journal of Plankton Research 3011: 1233-1243. 
Aracena C, C Lange, JL Iriarte, L Rebolledo \& S Pantoja. 2011. Latitudinal patterns of export production recorded in surface sediments of the Chilean Patagonian fjords (41$55^{\circ} \mathrm{S}$ ) as a response to water column productivity. Continental Shelf Research 31(3-4): 340-355.

Atlas E, S Hager, L Gordon \& P Park. 1971. A practical manual for use of the Technicon Autoanalyzer in seawater nutrient analyses revised. Technical Report 215, Reference 71-22, 49 pp. Oregon State University, Corvallis.

Avaria S, D Cassis, P Muñoz \& P Vera. 1997. Distribution of the marine micro phytoplankton in inland waters of southern Chile in October 1995 (Fjord Cruise Cimar-1). Ciencia y Tecnología del Mar 20: 107-123.

Barbieri MA, D Boré \& S Saéz. 2001. General information on the sea surface thermal structure of the area between the Gulf of Penas and the western mouth of the Strait of Magellan. Ciencia y Tecnología del Mar 24: 101-109.

Beckas L \& H Arndt. 2013. Different types of synchrony in chaotic and cyclic communities. Nature 1359 <doi:10.1038/ ncomms2355>

Brewin RJW, S Sathyendranath, T Hirata, S Lavender, R Barciela \& NJ Hardman-Mountford. 2010. A threecomponent model of phytoplankton size class for the Atlantic Ocean. Ecological Modelling 221: 1472-1483.

Brewin RJW, NJ Hardman-Mountford, SJ Lavender, DE Raitsos, T Hirata, J Uitz, E Devred, A Bricaud, A Ciotti \& B Gentili. 2011. An intercomparison of bio-optical techniques for detecting dominant phytoplankton size class from satellite remote sensing. Remote Sensing of Environment 115(2): 325-339.

Broitman B \& B Kinlan. 2006. Spatial scales of benthic and pelagic producer biomass in a coastal upwelling ecosystem. Marine Ecology Progress Series 327: 15-25.

Burrough PA. 1996. Principles of geographical information system for land resources assessment, $193 \mathrm{pp}$. Clarendon Press, Oxford.

Cáceres M, A Valle-Levinson \& L Atkinson. 2003. Observations of cross-channel structure of flow in an energetic tidal channel. Journal of Geophysical Research 108 (C4): <doi:10.1029/2001JC000968>.

Calvete C \& M Sobarzo. 2011. Quantification of the surface brackish water layer and frontal zones in southern Chilean fjords between Boca del Guafo (433' $\mathrm{S}$ ) and Estero Elefantes (46³0'S). Continental Shelf Research 31: 162171.

Canty MJ. 2006. Image analysis, classification and change detection in remote sensing with algorithms for ENVI/IDL, 348 pp. CRC Press, Boca Raton.

Carpenter J. 1965. The Chesapeake Bay Institute Technique for the Winkler dissolved oxygen method. Limnology \& Oceanography 10: 141-143.
Carrasco C \& N Silva. 2010. Comparison of the physical and chemical oceanographic features in the Puerto Montt to mouth Guafo between Winter and Spring of 2004 and between 1995 and 2004 Springs. Ciencia y Tecnología del Mar 33(2): 5-16.

Castillo M, O Pizarro, U Cifuentes, N Ramírez \& L Djurfeldt. 2012. Subtidal dynamics in a deep fjord of southern Chile. Continental Shelf Research 49: 73-89.

Clarke K \& RN Gorley. 2006. Primer v6: User manual/tutorial, 190 pp. Primer-E, Plymouth.

Clarke K \& R Warwick. 2001. Change in marine communities: an approach to statistical analysis and interpretation, 172 pp. PRIMER-E, Plymouth.

Dávila P, D Figueroa \& E Muller. 2002. Freshwater input into the coastal ocean and its relation with the salinity distribution off austral Chile $\left(35-55^{\circ} \mathrm{S}\right)$. Continental Shelf Research 22: 521-534.

Delgado L \& VH Marín. 2006. Determinación de zonas de alta concentración de clorofila-s en la región norte de los fiordos y canales australes (crucero Cimar 9 fiordos) por medio de sensoramiento remoto. Ciencia y Tecnología del Mar 29(2): 87-94.

Egge J \& D Aksnes. 1992. Silicate as regulating nutrient in phytoplankton competition. Marine Ecology Progress Series 83: 281-289.

Garrigues S, D Allard, F Barec \& J Morisette. 2008. Multivariate quantification of landscape spatial heterogeneity using variogram models. Remote Sensing of Environment 112(1): 216-230

Gerstmann C, M Miranda \& A Condal. 2010. Description of space-time variability of the potential productivity of Acacia caven espinales based on MODIS images and the Enhanced Vegetation Index (EVI). Ciencia e Investigación Agraria 37(1): 63-73.

Goldman J \& D McGillicuddy. 2003. Effect of large marine diatoms growing at low light on episodic new production. Limnology \& Oceanography 48: 1176-1182.

González HE, M Calderón, L Castro, A Clement, L Cuevas, G Daneri, JL Iriarte, L Lizárraga, R Martínez, E Menschel, N Silva, C Carrasco, C Valenzuela, CA Vargas \& C Molinet. 2010. Primary production and plankton dynamics in the Reloncaví Fjord and the Interior Sea of Chiloé, Northern Patagonia, Chile. Marine Ecology Progress Series 402: 13-30.

Hamm C, R Merkel, O Springer, P Jurkojc, C Maier, K Prechtel \& V Smetacek. 2003. Architecture and material properties of diatom shells provide effective mechanical protection. Nature 421: 841-843.

Iriarte JL, JC Uribe \& C Valladares. 1993. Biomass of sizefractionated phytoplankton during the Spring-summer season in southern Chile. Botanica Marina 36: 443-450. 
Iriarte JL, A Kusch \& M Ruiz. 2001. Phytoplankton biomass in the sub-Antarctic area of the Straits of Magellan $\left(53^{\circ} \mathrm{S}\right)$, Chile during spring-summer 1997-1998. Polar Biology 24: 154-162.

Iriarte JL, RA Quiñones \& RR González. 2005. Relationship between biomass and enzymatic activity of a bloom-forming dinoflagellate (Dinophyceae) in southern Chile $41^{\circ} \mathrm{S}$ : a field approach. Journal of Plankton Research 27: 159-166.

Iriarte JL, HE González, KK Liu, C Rivas \& C Valenzuela. 2007. Spatial and temporal variability of chlorophyll and primary productivity in surface waters of southern Chile 41.5-43ํ․ Estuarine Coastal Shelf Science 74: 471-480.

Iriarte JL, HE González \& L Nahuelhual. 2010. Patagonian Fjord Ecosystems in Southern Chile as a Highly Vulnerable Region: Problems and Needs. Ambio 39(7): 463-466.

Iriarte JL, S Pantoja \& G Daneri. 2014. Oceanographic processes in Chilean Fjords of Patagonia: from small to large-scale studies, Progress in Oceanography 129: 1-7. <doi: http://dx.doi.org/10.1016/j.pocean.2014.10.004>

Jeffrey SW, R Mantoura \& S Wright. 1997. Phytoplankton pigments in Oceanography, $661 \mathrm{pp}$. Monographs on Oceanographic Methodology, SCOR and UNESCO, Paris.

Kiørbe T. 1993. Turbulence, phytoplankton cell size, and the structure of pelagic food webs. Advances in Marine Biology 29: 1-73.

Lara C, M Miranda, V Montecino \& JL Iriarte. 2010. Chlorophyll- $a$ MODIS mesoscale variability in the Inner Sea of Chiloé, Patagonia, Chile (41-43 ${ }^{\circ}$ ): Patches and Gradients? Revista de Biologia Marina y Oceanografia 45(2): 217-225.

Marañón E. 2008. Inter-specific scaling of phytoplankton production and cell size in the field. Journal of Plankton Research 30: 157-163.

Marañón E. 2009. Phytoplankton size structure. In: Steele JH, KK Turekian \& SA Thorpe (eds). Encyclopedia of ocean sciences, pp. 4249-4256. Academic Press, Oxford.

Margalef R. 1958. Temporal succession and spatial heterogeneity in phytoplankton. In: Buzzati-Traverso AA (ed). Perspectives in marine biology, pp. 323-349. Berkeley, Los Angeles.

Margalef R. 1978. Life-forms of phytoplankton as survival alternatives in an unstable environment. Oceanologica Acta 1: 493-509.

Martin AP. 2003. Phytoplankton patchiness: the role of lateral stirring and mixing. Progress in Oceanography 57(2): 125174.

Miranda-Salas M \& A Condal. 2003. Importancia del análisis estadístico exploratorio en el proceso de interpolación espacial: caso de estudio Reserva Forestal Valdivia. Bosque 24: $29-42$.

Mitchell G, A Bricaud, K Carder, J Cleveland, G Ferrari, R Gould, M Kahru, M Kishino, H Maske, T Moisan, L Moore, N Nelson, D Phinney, R Reynolds, H Sosik, D
Stramski, S Tassan, C Trees, A Weidemann, J Wieland \& A Vodacek. 2000. Determination of spectral absorption coefficients of particles, dissolved material and phytoplankton for discrete water samples. In: Fargion GS \& JL Mueller (eds). Ocean optics protocols for satellite Ocean Color Sensor Validation, Revision 2, pp. 125-153. NASA, Greenbelt.

Montecino V \& D Quiroz. 2000. Specific primary production and phytoplankton size structure in the upwelling area off Chile $30^{\circ} \mathrm{S}$. Aquatic Science 62: 364-380.

Montecino V, MA Paredes, M Manley, R Astoreca, P Uribe, G Alarcón, G Pizarro \& C Vargas. 2006. Gradientes de productividad primaria, clorofila- $a$ y composición por tamaños del fitoplancton en canales occidentales de Aysén en noviembre 2002. Ciencia y Tecnología del Mar 29(2): 65-85.

Montecino V, P Uribe, D Soto, H González, J Riveros, G Alarcón, S Giglio, V Martínez \& MA Paredes. 2009. Bio-óptica y diversidad de tamaños del fitoplancton del mar interior de Chile: variabilidad espacial en invierno-primavera 2004 y 2005. Ciencia y Tecnología del Mar 32(2): 79-99.

Montero P, G Daneri, H Gonzalez, JL Iriarte, FJ Tapia, L Lizarraga, N Sanchez \& O Pizarro. 2011. Seasonal variability of primary production in a fjord ecosystem of the Chilean Patagonia: implications for the transfer of carbon within pelagic food webs. Continental Shelf Research 31(3-4): 202-215.

Moses WJ, AA Gitelson, S Berdnikov \& V Povazhnyy. 2009. Estimation of chlorophyll- $a$ concentration in case II waters using MODIS and MERIS data-successes and challenges. Environmental Research Letters 4 <doi:10.1088/1748-9326/ 4/4/045005>

Pantoja S, JL Iriarte \& G Daneri. 2011. Oceanography of the Chilean Patagonia. Continental Shelf Research 31(3-4): 149-153.

Paredes MA \& V Montecino. 2011. Size diversity as an expression of phytoplankton community structure and the identification of its patterns on the scale of fjords and channels. Continental Shelf Research 31: 272-281.

Paredes MA, V Montecino, V Anic, M Egaña \& L Guzmán. 2014. Diatoms and dinoflagellates macroscopic regularities shaped by intrinsic physical forcing variability in Patagonian and Fuegian Fjords and Channels $\left(48^{\circ}-56^{\circ} \mathrm{S}\right)$. Progress in Oceanography 129: 85-97.

Parsons T, M Takahashi \& B Hargrave. 1977. Biological oceanographic processes, 332 pp. Pergamon Press, Oxford.

Pickard G. 1970. Some physical oceanographic features of inlets of Chile. Journal of Fisheries Research Board of Canada 28: 1077-1106.

Pizarro G, JL Iriarte, V Montecino, JL Blanco \& L Guzmán. 2000. Distribución de la biomasa fitoplanctónica y productividad primaria máxima de fiordos y canales australes $\left(47^{\circ} 50\right.$ 'S) en octubre 1996 . Ciencia y Tecnología del Mar 23: 25-48. 
Ramírez B \& E Pizarro. 2005. Distribución de clorofila $a$ y feopigmentos en los canales australes chilenos comprendidos entre Puerto Montt y laguna San Rafael, Chile. Ciencia y Tecnología del Mar 28(1): 45-62.

Rebolledo L, H González, P Muñoz, JL Iriarte, C Lange, S Pantoja \& M Salamanca. 2011. Siliceous productivity changes in Gulf of Ancud sediments $\left(42^{\circ} \mathrm{S}, 72^{\circ} \mathrm{W}\right)$, southern Chile, over the last $\sim 150$ years. Continental Shelf Research 31(3-4): 356-365. <doi:10.1016/j.csr.2010.06.015>

Reynolds C. 1988. Functional morphology and the adaptive strategies of freshwater phytoplankton. In: Sandgren CD (ed). Growth and reproductive strategies of freshwater phytoplankton, pp. 388-433. Cambridge University Press, Cambridge.

Ross L, I Pérez-Santos, A Valle-Levinson \& W Schneider. 2014. Semidiurnal internal tides in a Patagonian fjord. Progress in Oceanography 129, Part A: 19-34.

Sabetta L, A Fiocca, L Margheriti, F Vignes, A Basset, O Mangoni, G Carrada, N Ruggieri \& C Ianni. 2005. Body size-abundance distributions of nano- and microphytoplankton guilds in coastal marine ecosystems. Estuarine, Coastal Shelf Science 63: 645-663.

Sánchez G, E Morales \& E Quillot. 2003. Response of the diatom Actinocyclus normanii Hustedt to variations in initial cellular density, salinity, silicate, and phosphate concentrations in laboratory conditions. Boletín de Investigaciones Marinas y Costeras 32(1): 169-181.

Sievers AH \& N Silva. 2008. Water masses and circulation in austral Chilean channels and fjords. In: Silva N \& S Palma (eds). Progress in the oceanographic knowledge of Chilean inner waters, from Puerto Montt to Cape Horn. pp. 53-58. Comité Oceanográfico Nacional / Pontificia Universidad Católica de Valparaíso, Valparaíso.

Silva N \& D Guzmán. 2006. Condiciones oceanográficas, físicas y químicas, entre boca del Guafo y fiordo Aysén (Crucero Cimar 7 Fiordos). Ciencia y Tecnología del Mar 29(1): 25-44.

Silva N \& S Palma. 2006. Avances en el conocimiento oceanográfico de las aguas interiores chilenas, Puerto Montt a Cabo de Hornos, 162 pp. Comité Oceanográfico NacionalPontificia Universidad Católica de Valparaíso, Valparaíso.

Silva N, H Sievers \& R Prado. 1995. Descripción oceanográca de los canales australes de Chile. Zona Puerto-Laguna San Rafael (41 $20^{\circ}$ 'S, 46 40'S). Revista de Biologia Marina 30(2): 207-254.
Silva N, C Calvete \& H Sievers. 1997. Características oceanográficas físicas y químicas de canales australes chilenos entre Puerto Montt y Laguna San Rafael (Crucero CIMAR Fiordo 1). Ciencia y Tecnología del Mar 20: 23106.

Silva N, C Calvete \& H Sievers. 1998. Masas de agua y circulación general para algunos canales australes entre Puerto Montt y Laguna San Rafael, Chile (Crucero CIMARFiordo 1). Ciencia y Tecnología del Mar 21: 17-48.

Stewart A, EA John \& JM Hutchings. 2000. The world is heterogeneous: ecological consequences of living in a patchy environment. In: Hutchings JM, EAJohn \& A Stewart (eds). The ecological consequences of environmental heterogeneity, pp. 1-8. Blackwell Science, London.

Strickland J \& T Parsons. 1972. A practical handbook of seawater analysis. Bulletin, Fisheries Research Board of Canada 167: 1-20.

Tello A \& C Rodríguez-Benito. 2009. Characterization of mesoscale spatio-temporal patterns and variability of remotely sensed Chl $a$ and SST in the Interior Sea of Chiloe 41.4-43.5 ${ }^{\circ}$ S. International Journal of Remote Sensing 306: 1521-1536.

Torres R, M Frangopulos, M Hamame, V Montecino, C Maureira, G Pizarro, B Reid, A Valle-Levinson \& JL Blanco. 2011. Nitrate to silicate ratio variability and the composition of micro-phytoplankton bloom in the innerfjord of Seno Ballena (Strait of Magellan, $54^{\circ} 1 \mathrm{~S}$ ). Continental Shelf Research 31(3-4): 244-253.

Uribe J. 1992. Fitoplancton en los fiordos magallánicos. In: Gallardo VA, O Ferreti \& HI Moyano (eds). Oceanografía en Antártica, pp. 467-478. Centro EULA/Universidad de Concepción, Concepción.

Vargas C, R Martínez, V San Martin, M Aguayo, N Silva \& R Torres. 2011. Allochthonous subsides of organic matter across a lake-river-fjord landscape in the Chilean Patagonia: Implications for marine zooplankton in inner fjord areas. Continental Shelf Research 31: 187-201.

Valenzuela M \& S Avaria. 2009. Distribución del microfitoplancton marino entre el seno Reloncaví y Boca del Guafo en invierno y primavera de 2005 (crucero CIMAR 11 fiordos). Ciencia y Tecnología del Mar 32(2): 43-77.

Weiss R. 1970. The solubility of nitrogen, oxygen and argon in water and sea water. Deep-Sea Research 17: 721-735.

Received 5 February 2014 and accepted 6 December 2014

Editor: Claudia Bustos D. 